University of Michigan Law School

University of Michigan Law School Scholarship Repository

Articles

Faculty Scholarship

1922

\title{
The United States and World Organization
}

Edwin D. Dickinson

University of Michigan Law School

Available at: https://repository.law.umich.edu/articles/995

Follow this and additional works at: https://repository.law.umich.edu/articles

Part of the International Law Commons, Military, War, and Peace Commons, and the Organizations Law Commons

\section{Recommended Citation}

Dickinson, Edwin D. "The United States and World Organization." Am. Pol. Sci. Rev. 16 (1922): 183-93.

This Article is brought to you for free and open access by the Faculty Scholarship at University of Michigan Law School Scholarship Repository. It has been accepted for inclusion in Articles by an authorized administrator of University of Michigan Law School Scholarship Repository. For more information, please contact mlaw.repository@umich.edu. 


\section{The American Political Science Review}

\begin{tabular}{lll}
\hline \hline Vol. XVI & MAY, 1922 & No. 2 \\
\hline \hline
\end{tabular}

\section{THE UNITED STATES AND WORLD ORGANIZATION}

\section{EDWIN D. DICKINSON \\ University of Michigan}

On what conditions should the United States enter a world organization for the maintenance of peace? Viewing the question broadly, should not the United States enter world organization upon one condition, namely, that the organization give promise of the utmost achievement in the maintenance of peace? Unless we are prepared to repudiate the avowals of our statesmen and reverse what is perhaps the oldest and most fundamental tradition of our foreign policy, can we consistently insist upon any other condition than this one?

A good deal has been said of late about the "American idea" in international relationships. It has been suggested that the "American idea" was defined in Washington's farewell address, in the Monroe Doctrine, or in America's participation in the peace conferences held at The Hague. It seems evident, however, that this involves a confusion of the idea with its occasional manifestation in action. If there is any one outstanding "American idea" which has inspired our foreign policy from the beginning -any quintessence of principle which may be derived alike from the first neutrality proclamation, the farewell address, Monroe's message, Hay's pronouncement for the open door, or America's participation in the conferences at The Hague - that idea is the maintenance of just and honorable peace. 
If peace has been our loadstar, expediency has been our guidepost. One hundred and twenty-five years ago, in the year of Washington's farewell address, "our detached and distant situation" made a policy of aloofness the most effective way of maintaining peace in the western world. One hundred years ago, when the political stage was being set for Monroe's epoch-making message, the governmental systems prevailing elsewhere were "essentially different . . . . from that of America" and any attempt to extend such systems to the western hemisphere would have been "dangerous to our peace and safety." At the end of the century, on the other hand, Secretary Hay found it the part of wisdom to "act concurrently with the other powers" in protecting interests and restoring peace in China. And only recently "the utmost practicable coöperation in counsel and action" with the states then at war with Germany was thought necessary to "vindicate the principles of peace and justice in the life of the world." While the aspiration for peace has been manifested in each great pronouncement, the measures taken have been wisely determined by time and circumstance.

It seems a mere truism to say that time and circumstance are now compelling us to place new emphasis upon the importance of world organization. The world needs peace and security for peace as the world has never needed it before. Nor is this a circumstance which the United States can safely ignore. The progress of events has been irresistibly "interweaving our destiny" with that of the rest of the world, so that the world's need has become our need, and from motives generous or selfish, as you please, we must view the problem very much as the rest of the world is obliged to view it. In the light of these reflections, should we not reformulate the question and inquire, What sort of world organization promises most in security for peace?

There is at least one consideration which should never escape us. The organization of the world which promises most in security for peace will be neither the state of nature nor the superstate, neither Hell nor Utopia. If the idea of an international state of nature was conceived as the beatification of chaos, it has become in the modern world a monstrosity of the imagination. 
In the place of chaos there has evolved a vaguely defined and somewhat protoplasmic organization of the international community. This must provide the essential groundwork. The world organization of the future, far from resembling Utopia, must consist of "a duller and heavier structure placed logically upon the foundations of the existing system."

It is possible, of course, to build upon the existing foundations and yet choose wisely or unwisely in planning the superstructure. There are those who believe that we are confronted in this respect with a choice of far-reaching import. It has been asserted that the alternatives are an association of nations, on the one hand, and a confederacy of nations on the other. It has been urged that the idea of friendly and more or less informal association was exemplified in the Pan-American conferences and the peace conferences at The Hague, while confederacy finds expression in the League of Nations. I would like to submit, in the first place, that these alternatives are by no means so sharply defined and mutually exclusive as seems to have been assumed, and in the second place, that in so far as they are mutually exclusive, there should be no real doubt about the choice which the United States is required to make.

The alternatives are neither well defined nor mutually exclusive. Consider the idea of association among nations as exemplified in the Hague peace conferences. Such conferences are interesting and important phenomena, but they are only a part of the picture. Indeed, we have achieved much more in the way of world organization than any study of such conferences can possibly disclose. The Hague conferences, for example, made no contribution whatever to international administration and were in no definite way associated with its development. And yet the growth of administrative unions was undoubtedly one of the most significant developments of the past half century. It is noteworthy that the United States took an active and influential part. Again, by way of providing for the peaceful settlement of international disputes, the Hague conferences created the socalled Permanent Court of Arbitration. In the recent recrudescence of pessimism, this institution has come to be regarded in 
some quarters as a unique expression in world organization of the association idea. It seems to have been forgotten that in the conferences which formulated the plan the principal merit claimed for it was the superiority of something over nothing. Has it also been forgotten that the best effort of the Second Hague Conference was spent upon an attempt to formulate a plan for a real international court of justice and that this effort was initiated and supported vigorously by the government of the United States? It is well known that the effort failed because of inability to reach an agreement upon the court's composition. It may be confidently asserted, nevertheless, that in preparing the way for future agreement this abortive attempt was really the Second Conference's most substantial achievement. Finally, the Hague conferences afforded an opportunity for the friendly discussion and adjustment of political questions. It is urged that we should revive the conferences and perpetuate them. This is a proposition entitled to consideration on its merits. In the meantime, however, it should be remembered that more was actually done for the maintenance of peace in the past century by another type of conference in which participation was more limited, procedure less formal, and achievement more relevant to the world's immediate need. What survey of progress made in the development of world organization during the past century can neglect the much maligned concert of the great powers, in which the United States before the World War had begun to take an active interest, with which it had on occasion consented to coöperate, and which it has recently summoned to our own capital to consider certain of the more pressing international problems of the present day. Let us complete the picture. Let us regard all that the nations have achieved through generations of struggle as a somewhat coherent though primitive organization. We see a remarkable accumulation of administrative institutions which has evolved more or less spontaneously to meet international needs. We see fruitful experiments with arbitration, arbitration dignified in the Hague Tribunal, and the foundations laid for an international court of justice. We see international conferences innumerable, including those which have been broadly represen- 
tative, and which have debated much but settled little, and also those which have wielded power, though sometimes, it has seemed, without much regard for justice. If we were to frame a constitution for this complex organism, expressing accurately its true significance, it is evident that the constitution would have to provide for something much more substantial and complete than intermittent and friendly association.

If those who urge the idea of association as opposed to confederacy really mean that we should revert to Hague arbitrations, Hague conferences, and the like, instead of going ahead to build more boldly upon existing foundations, there should be no uncertainty about the decision. The time has surely come when it will be advantageous at least to coördinate the sprawling growth of international administrative institutions under more systematic and centralized supervision. Nor is there any reason of expediency or principle why this should not be done. The time has come also when the nations require an institution more convenient, more permanent, more of the nature of a court than the very imperfect contrivance devised at The Hague and known as the Permanent Court of Arbitration. This so-called Permanent Court is not permanent. It is not a court. It provides only a transitory forum which is too unwieldy and expensive for the less important cases. It has no continuity, no history, no record of past performance, and is too inconstant for many of the more important cases. Leaving out of calculation the years of war, the so-called Permanent Court of Arbitration has decided an average of less than one case a year. A few of its awards, as in the Pious Fund or the Savarkar case, would have been creditable to a court of justice. Others have presented the characteristics of arbitration, notably the North Atlantic Fisheries award, giving Great Britain two big fishes and the United States five little ones, and the Casablanca award, deciding that whereas conflict results from the collision of two incompatible forces the German consular authorities in Morocco could not be blamed for a grave and manifest error. Let the system of arbitration be retained for the settlement of controversies in which arbitration is appropriate. But let us have also a court before which may be made a very 
humble and a very modest beginning in developing the processes of international justice. Finally, has not the time arrived when the United States ought to be more candid about its intention of coöperating, not only in regional conferences like the Pan-American, and general conferences like those held at The Hague, but also in conferences like the one held recently at Washington in which the great powers concert together. It is certain that the United States will participate in many assemblies and councils of both types. Experience has demonstrated that each has a useful function to perform as a peace-promoting agency in international affairs. Then why not be candid, in the interest of simplification and certainty, and enter into an agreement with other nations for the summoning periodically of conferences of either sort linked together by the useful fiction of continuity. Why not take the system of international conferences which has grown up in the past and make it more efficacious by giving it a plan. If this is the difference between association and confederacy, then why not accept confederacy.

There are practical disadvantages, it must be admitted, in any program which aims to create a more formal association or confederacy among nations. A program always excites quiescent issues. Difficulties which time is competent to remove in an evolutionary process become acute and sometimes insurmountable. Attrition is easier than the grand strategy.

As soon as it is proposed that nations organize their association more systematically, serious difficulty is encountered in determining the measure of each nation's participation. How shall we apportion representation in council, court, or conference? How shall we distribute votes if there is to be voting, or expense if there is to be a budget? There are great powers and small powers, strong powers and weak powers, powers which are advanced in the civilization which is characteristic of the twentieth century and others which are backward. The great powers will not submit really important decisions to a tribunal or conference which may be dominated by the small, weak, or backward states. The lesser states know all too well the dangers which inhere in the predominance of the great. Upon what basis is it possible to 
constitute an organization including sixty or more nations so as to satisfy the powerful, safeguard the weak, assure adequate representation to every factor, and yet attain an organization which is wieldy enough to serve some useful purpose in providing security for peace?

The difficulty becomes more evident as we consider the extraordinary group of empires, nations, states, and quasi-states with which we have to deal. There are between sixty and seventy political entities in the world today (not including Andorra, Lichtenstein, Monaco, and San Marino) which may fairly claim some consideration in any program of world organization. These entities divide the earth among themselves with little regard for the cartographer's convenience. One is a mere pin point of color. Another covers a great portion of the map with red or brown or blue. Ten have a territorial area of upwards of a million square miles, while twenty-eight reckon area in six figures and twenty-nine reckon it in five figures. If territorial area were to be accepted as a standard by which to measure the right to participate in world organization, Japan might rank as low as twenty-third or twenty-fourth, being outranked by such countries as Abyssinia, Colombia, Persia, Peru, and Venezuela. Diversities of population are quite as extraordinary as diversities of area. The British Empire as a whole claims over 440 million. China claims 400 million and probably has at least 325 million. India claims more than 300 million. Including India as a separate entity, there are five countries which have a population well over 100 million, while figures for the French empire fall but little short of that number. On the other hand, seventeen countries, not including the French colonial empire, compute population in eight figures, twenty-eight compute it in seven figures, and ten compute it in only six figures. Estimates of area and population suggest only the more striking differences. There are maritime states and inland states, states which are dependent upon overseas commerce and others which are nearly self-sufficient. There are sea powers, land powers, and states of no military power at all. There are states or quasi-states united loosely in imperial union, and others which admit no ties except those of 
the great community. There are states which live in the penumbra of another's hegemony, and quasi-states under guarantee, protection, or mandate. There are states-but why elucidate the obvious? The problem of formulating a satisfactory scheme of participation in world organization is one of unusual difficulty.

Experience indicates, nevertheless, that the problem may be solved. There are several factors of which account will have to be taken. Perhaps the most important of these factors is the distribution of the world's population. Prepossessed by tradition, we have been inclined hitherto to make too much of the state, the Great Leviathan, and not enough of humanity. We have been unmindful at times of the principle that organization and law are justified only as they promote the welfare of the human beings whom they are intended to serve. International organization and law must be justified by the same test. This means that organization must in some degree represent and be responsive to human beings who inhabit the earth. The practicability, the necessity indeed, of taking this factor into account has been indicated in the spontaneous development of international conferences. While we have had regional conferences and general conferences in which many states participated equally, really contentious issues have usually been referred to smaller conferences in which the great powers were dominant. It is noteworthy that the great powers today are included among the nine countries which rank highest in population and that the other countries included are China, India, Russia, and Germany. Population is an important factor, but not the only one of which account must be taken. A numerous people with an imperfectly developed economic or political organization cannot hope to exercise as much influence in world affairs as a less numerous but more coherent people. Economic or political upheavals may temporarily eclipse international power. It is apparent that we must also give attention to what may be described, for want of a better term, as qualitative criteria.

From brief suggestion of a feasible approach to principle, let us turn to consider the principle's application in a plan. When the time comes to draft a plan of organization, can we possibly 
do better than to make two series of conferences an outstanding feature of the proposed organization? We may provide for periodic conferences in which all nations participate equally and also for conferences in which the nations greatest in population and influence shall have a majority of the representation. We may provide that these two series of conferences shall function concurrently. The idea is an old one which has been urged many times by illustrious advocates. It has been approved in the recent treaties and embodied in the League of Nations. More recently, the existence of such a twofold representation in the league has made it possible, for the first time, to secure an agreement among great states and small states on a plan for a permanent international court of justice. As the brief history of the Council and Assembly of the League has already demonstrated, the bi-conference plan does not resolve all difficulties. But it does provide a reasonable basis for compromise. It has a real foundation in the experience of history. And by making it possible to organize the processes of peace it prepares the way for more useful developments in the future.

Another difficulty results from the desire to invest world organization with power. It is said that international law must have sanctions, that we must have an organization "with teeth." This is an aspect of the quesion about which reasonable men may disagree. It is my own opinion that we are in danger of confusing a vague ideal with the immediate opportunity. There is no conceivable kind of world organization, with or without power, which can certainly maintain peace. The German confederation did not maintain peace among its members; neither did the federal constitution of the United States; neither has British imperial union. Who can view realistically this distrustful and distracted world and hope that world organization may accomplish more? Is there not grave danger, indeed, that world organization incorporating the sanctions of affirmative covenants, joint force, or the boycott may cause more irritation than it allays and may actually be provocative of war. This is the most serious defect in the plan of the Paris treaties. Not content with negative covenants and moral sanctions, the framers sought to include 
affirmative covenants and physical sanctions. And to cap the climax of that scheme's iniquities, they compromised the whole plan by linking it up with an impossible settlement, actually giving the league more power to enforce the settlement than it has to preserve peace. Disentangled from the European treaties of peace, its covenants construed as self-denying and its guaranties as voluntary, the League of Nations presents an altogether admirable scheme of organization. It is a great misfortune that the United States has not found a way, safeguarded by adequate reservations, to participate in its councils and in the new court of justice which it has just created. We cannot hope to maintain peace either with or without affirmative covenants and physical sanctions, until the slow processes of evolution through education have taught us to think and act differently in international relationships. The immediate opportunity is a more modest one. By organization we may conserve what has already been achieved. The importance of this is not always appreciated. We may also equip ourselves much more effectively to meet current international needs. And, above all, we may direct and hasten the processes of evolution by strengthening and improving the foundations upon which the superstructure of peace must eventually repose.

It has been my purpose to suggest that world organization ought to be grounded solidly upon the foundations laid in past experience, that this has been satisfactorily achieved in the structure of the existing league, but that world organization for the present should be without affirmative covenants or sanction of physical force. Such a program is conservative. Is it worth effort and sacrifice? It seems to me that it is not only worth effort and sacrifice, but that it offers what is perhaps the greatest opportunity for constructive achievement in international affairs since the time of Grotius.

Consider the effect of such an organization upon the development of international law. It will be agreed, no doubt, that a conspicuous imperfection in international law has been its unreality - the impractical and unsubstantial character of many of its rules. This has been due largely to the circumstance that of 
all formulating agencies the juristic writings have been easily the most influential. There has been nothing in international law that is really comparable to the influence of judicial decisions, administration, and legislation upon the growth of municipal law. Modern developments in international organization have begun to exert faintly an influence which is somewhat comparable. Is it too much to hope that a program of world organization may accelerate and strengthen this tendency and so make it possible eventually to redeem the law of nations from its unreality.

It will be agreed also that another characteristic defect in international law is its confusion at many points with the uncertainties and intrigues of diplomacy. How much depends, for illustration, upon the anomalous rule in regard to recognition. By withholding recognition a new community may be deprived, with disastrous effect, of the status to which it ought to be entitled, or an old state may be partially outlawed by refusing to recognize a change in government. And the decision or decisions in each instance may be made in secret in the foreign offices of the more influential powers. This, from the legal point of view, is an abominable situation. With the nations organized, there need be no justification for its continuance. In this and other respects it may be possible through organization to develop clearer delimitations between the province of international law and the domain of the diplomat. Finally, who would deny that the gravest of all deficiencies in a very imperfect system has been the meager development of peaceful remedial processes and the remarkable emphasis placed upon war. World organization should change the emphasis. Instead of peace conferences devoted to the laws of war, we may hope for peace conferences concerned with the laws and problems of peace. The way will be prepared for the development of the most undeveloped and most important part of the international system.

World organization promises no millennium, but it does promise new and greater opportunities for progress in the maintenance of peace. By the fundamental traditions of its foreign policy and by every consideration of self-interest, the United States is required to take a helpful and an influential part. 